\title{
ВОПРОСЫ ФАКТА И ПРАВА: НЕОБХОДИМОСТЬ ТЕОРЕТИЧЕСКОГО ИССЛЕДОВАНИЯ
}

\author{
(C) 2020 Зеленин Никита Юрьевич \\ аспирант кафедры ТГиП Школы права Института права и управления \\ Московский городской педагогический университет, Россия, Москва \\ E-mail: mail.nikitazelenin@gmail.com
}

Российское право, судебные решения, отечественная правовая наука нередко оперируют дихотомией вопросы факта-вопросы права. При этом названная пара довольно абстрактна для российских юристов-практиков и незаметна в отечественных научных кругах. Настоящая работа имеет цель обнаружить значимость изучаемых явлений для отечественной юриспруденции в целом и теории права в частности.

Ключевые слова: вопросы факта и права, правоприменение, реализация права, норма права, юридический факт, преюдиция, преюдициальность, кассационный процесс, суд присяжных.

Судья при вынесении судебного решения, равно как и любой юрист, уясняющий сущность определенной правовой ситуации, должен ответить на 2 категории вопросов: факта и права. Иными словами, необходимо определить на основании доказательств некий перечень относимых к делу фактических обстоятельств, а также дать им соответствующую правовую оценку, ответив на вопрос, что следует из таких обстоятельств.

На первый взгляд, разграничить названные категории несложно, однако первое впечатление традиционно обманчиво. Многие институты права в целом, российского права в частности в той или иной степени оперируют рассматриваемой дихотомией, обнаруживая ее неразрывную связь с одной стороны, разграничивая - с другой:

- Issues of fact and law (вопросы факта и права) - хорошо известная англо-американским юристам концепция, преимущественно (но не исчерпывающе) связанная с распределением вопросам, подлежащих разрешению судом или присяжными. Такое разделение известно и российскому праву и закреплено в положениях статей 299, 334 УПК РФ.

- При принятии решения суд оценивает доказательства, определяет, какие обстоятельства, имеющие значение для рассмотрения дела, установлены и какие обстоятельства не установлены (прим. автора - вопросы факта), каковы правоотношения сторон, какой закон должен быть применен по данному делу и подлежит ли иск удовлетворению (прим. автора - вопросы права) [7: ч. 1 ст. 196; 3: ст. 168].

- Традиционно суды высоких инстанций проверяют решения нижестоящих судов в части правильности применения норм права, но не оценивают доказательства. Например, в российском процессе суд кассационной инстанции не вправе переустанавливать факты дела, не может оценивать доказательства по спору - он проверяет правильность применения норм права, соответствие выводов судов нижестоящих инстанций материалам дела [3: ч. 1, 3 ст. 286, п. 2 ч. 1 ст. 287, ч. 2 ст. 287].

Однако российские законодатели, суды и правоведы пока не проявляют значительного интереса к понимаю причин и следствий разграничения вопросов факта и права, что отмечают и другие исследователи [5, с. 1].

Для начала концептуального исследования рассматриваемого вопроса необходимо определить его место в структуре юриспруденции как науки, его теоретическую основу. Исследование соотношения вопросов факта и права невозможно без определения первичных по отношению к рассматриваемой теме понятий: право, юридический факт, норма права.

Традиционно в отечественных учебниках и монографиях по теории государства и права не рассматривается теоретическая основа разделения вопросов факта и права, как и не дается определения самому понятию «вопроса» в контексте изучаемой темы. Между тем, научные работы отраслевого характера нередко содержат упоминания названной концепции $[2 ; 5 ; 6 ; 15 ; 25]$.

Не останавливаясь подробно на вопросах 
правопонимания, как на более сложной и глубокой для теории права теме, используем наработки научно обоснованной интегративной теории правопонимания и выберем исходным понимание права, предлагаемое профессором Ершовым, и определяемое как прежде всего принципы и нормы права, содержащиеся в единой, развивающейся и многоуровневой системе форм национального и (или) международного права, реализующихся в государстве [10].

Определение нормы права дается с помощью перечисления ее основных и неотъемлемых признаков и, по мнению автора, является одним из наименее спорных в отечественной теории. Наиболее классическим является такое, при котором норма права определяется как общеобязательное, формально определенное правило поведения, установленное либо санкционированное государством и направленное на урегулирование общественных отношений [14]. Названное определение считаем наиболее подходящим.

Факты и ключевое для этой темы понятие «юридический факт» традиционно изучаются в контексте раздела общей теории правоотношений теории права [16, с. 244]. Привычным и наиболее точным определением, по мнению автора, является такое, при котором юридические факты представляются сформулированными в гипотезах правовых норм жизненными обстоятельствами, с которыми закон связывает возникновение, существование, изменение или прекращение правовых отношений [13].

Таким образом, напомнив содержание базовых понятий, мы обязаны определить, что ключевым для рассматриваемой темы тезисом является идея о том, что, говоря о концепции «вопросов факта и права», мы имеем ввиду не собственно вышеуказанные разделы теории права, не соотношение и разделение понятий «норма права» и «юридический факт». Место исследуемой концепции в теории права, по мнению автора, находится много ближе к теории реализация права.

Право как совокупность общеобязательных правил поведения только тогда выполняет свое основное социальное назначение, когда оно реализуется, приводится в движение [22]. Под реализацией права уместно понимать претворение, воплощение предписаний юридических норм в жизнь путем правомерного поведения субъектов общественных отношений (государствен- ных органов, должностных лиц, общественных объединений, физических лиц) [16, с. 249]. Необходимо понимать, что право реализуется в различных формах: обычно выделяют четыре формы реализации права - соблюдение, исполнение, использование и применение. С исследуемой темой непосредственно связана последняя из названных форм.

Под правоприменением мы понимаем форму реализации права, при которой нормы права реализуются посредством действий должностных лиц компетентных органов государственной власти (судов, правоохранительных органов и так далее).

Традиционно теоретики права выделяют 3 стадии правоприменения: определение и установление фактических обстоятельств дела, юридическая квалификация установленных фактических обстоятельств дела, принятие решения по юридическому делу [1].

Интересной и наиболее обоснованной представляется классификация, предложенная СардаевойО.Г., согласно которой к классическим трем добавляется четвертая стадия: исполнение принятого юридически значимого решения [23]. Такая концепция применяется и другими исследователями [16].

Для целей настоящей работы вопрос о четвертой стадии не является ключевым, поэтому цитируя В.В Лазарева, описывающего 3-стадийную модель стадий правоприменения, остановимся на ней, поскольку «приведенная классификация соответствует пониманию процесса применения права как решения известного силлогизма. Вначале устанавливаются малая и большая посылки, а затем происходит подведение первой под вторую. Было бы неверным сводить правоприменительную деятельность лишь к вынесению решения» [12].

Таким образом, становится очевидно, что разрешение вопросов факта и вопросов права коррелирует со стадиями правоприменительного процесса и, тем самым, отчасти находит свое место в системе теории права. Однако, по мнению автора, стоит понимать и разграничивать понятие «разрешение вопросов факта и права» в узком и широком смыслах.

В узком смысле под разрешением вопросов факта и права мы понимаем совершаемую в процессуальной форме деятельность уполномоченного лица (субъекта правоприменительного процесса). В этом случае процесс разрешения 
вопросов факта и права тождественен первым двум стадиям правоприменительного процесса, а их целью и результатом является принятие решения по юридическому делу.

В широком - мы понимаем умственнологическую деятельность участника правоприменительного процесса, связанную с формированием собственных ответов на уясненные и поставленные вопросы факта и права. В этом случае целью разрешения вопросов является не принятие решения по делу, а выработка собственной правовой позиции. В рамках исследования поставленной темы мы чаще будем использовать более широкую точку зрения.

Так, при формировании правовой позиции участник (а при принятии решения по делу субъект) правоприменительного процесса, уясняет и разрешает вопросы факта и права, то есть формирует логические заключения о том, какие фактические обстоятельства имели место и какие правовые последствия они вызывают.

Исходя из вышеизложенного, под вопросами факта и права можно понимать обстоятельства (юридические факты и их правовую квалификацию), подлежащие уяснению и разрешению участником правоприменительного процесса при выработке правовой позиции по конкретному делу.

Уяснить вопросы факта и права - значит определить, какие относимые к делу фактические обстоятельства подлежат установлению, на основании каких доказательств они могут быть установлены, по каким из них имеется спор и какие из них подлежат правовой квалификации.

Разрешить вопросы факта и права - значит сформировать ответы на уясненные и поставленные вопросы.

Стоит особо отметить, что вышеуказанные положения как о месте концепта в системе теории права, так и предложенные определения, не являются бесспорными, но призваны обратить внимание на необходимость теоретического исследования концепта разграничения вопросов факта и права и обоснованность его применения как в обучении, так практической деятельности. Такая необходимость проявляется влиянием на многие сферы.

Во-первых, четкое разграничение вопросов факта и права обязательно для понимания и определения правил пересмотра судебных решений в вышестоящих инстанциях.

В России суды кассационных инстанций (в отличие от апелляционного производства) по общему правилу не вправе переустанавливать фактические обстоятельства, то есть проверяют ошибки в вопросах права, но не вопросах факта. Например, основаниями отмены приговора при рассмотрении уголовного дела в кассационном порядке являются существенные нарушения уголовного и (или) уголовно-процессуального закона [24: ч. 1 ст. 401.15]. Апелляционный суд же находит основание отмены судебного решения в случае несоответствия выводов суда, изложенных в приговоре, фактическим обстоятельствам уголовного дела, установленным судом первой инстанции [24: п. 1 ст. 389.15]. Приговор признается не соответствующим фактическим обстоятельствам уголовного дела, установленным судом первой инстанции, если выводы суда не подтверждаются доказательствами, рассмотренными в судебном заседании согласно [24: п. 1 ст. 389.16]. Похожие по своей сущности положения закреплены в иных российских процессуальных кодексах [3: ч. 1,3 ст. 286, п. 2 ч. 1 ст. 287, ч. 2 ст. 287 ; 7 : ч. 1 ст. 379.6 , ч. 1 ст. 379.7 , ч. 3 ст. 390].

Таким образом, законодатель на нормативном уровне ограничивает полномочия высоких судов вопросах установления фактических обстоятельств дела. Указанное объективно обуславливается более низкой вовлеченностью кассационной коллегии в обстоятельства конкретного спора.

Аналогичные правила находят свое отражение и в иных правопорядках. В США в федеральной системе судов существует три инстанции: окружные суды (district court), апелляционные суды (Court of Appeals) и Верховный Суд (U.S.Supreme Court). Вопросы факта разрешаются окружными судами (то есть судами первой инстанции), в соответствующих случаях - c участием присяжных. К установленным таким образом фактам судья первой инстанции (trial judge) применяет нормы статутного и прецедентного права. Апелляционный суд исправляет ошибки нижестоящих судов в вопросах права [5, c. 7-8].

Однако названное правило осложняется существованием вопросов пограничного характера, часто называемых «смешанными» [5, с.4]. Было ли поведение стороны договора добросовестным, проявил ли подсудимый неосторожность, разумны ли понесенные расходы? Являются ли ответы на указанные вопросы результатом разрешения вопросов факта, либо это 
последствия правовой оценки поведения субъекта правоотношения?

Ответы на вышеуказанные вопросы часто могут быть обнаружены в научных и практических работах отраслевого характера, но даже в таком случае часто остаются спорными и не разрешенными.

Таким образом, четкое понимание и разграничение вопросов факта и права для целей пересмотра судебных решений необходимо как правоприменителю, так и участнику правоприменительного процесса.

Во-вторых, отделение вопросов факта от вопросов права имеет значение для преюдициальности актов индивидуального регулирования, в частности судебных актов.

Как указывала М.А.Ерохова, применение правил о преюдиции порождает в современной российской практике множество проблем, например, можно ли опровергнуть преюдицию путем представления новых доказательств в другом деле; распространяется ли преюдиция на правовые выводы судьи [9].

Действительно, что такое обстоятельства, установленные судом? Факты (вопросы факта) или факты с правовыми оценками (вопросы права). Являются ли преюдициальными выводы об уже упоминаемых нами выше вопросах о добросовестности, неосторожности, разумности?

В основе института преюдиции лежит аксиома истинности вступившего в законную силу судебного акта - res judicata pro vetitate habetur (лат. «судебное решение должно принимать за истину») [4].

Поскольку целью института преюдиции является обеспечение соблюдения принципа правовой определенности, в том числе путем поддержания непротиворечивости судебных актов, в доктрине имеет место позиция, при которой изучается преюдиция не как доказательство, а как один из эффектов судебного решения и включает в себя и выводы о факте, и выводы о праве [9]. При этом правоприменительная практика обнаруживала и обратный подход, при котором преюдициальность освобождает от доказывания фактических обстоятельств дела, но не исключает их различной правовой оценки. Вопросы правовой квалификации преюдициального значения не имеют $[17 ; 18 ; 20 ; 21]$.

Тем самым для определения пределов преюдициальности правоприменительного акта непосредственное значение имеет концепция разграничения вопросов факта и права.

В-третьих, концепт связан с правилами постановки вопросов присяжным в уголовном процессе, не только отечественном, но в иных правопорядках.

Само возникновение концепции разграничения вопросов факта и права как явления не только логического, но и институционального было связано с развитием и закреплением принципа судопроизводства ad quaestionem facti non respondent judices, ad quaestionern juris non respondent juratores (вопросы факта не решают судьи, вопросы права не решают присяжные) [26]. Так, четкая связь между устройством суда присяжных и разграничением вопросов факта и права обнаруживается к середине XV века в английском праве [11]. Названный принцип находит свое отражение в современном законодательстве [24: ст. 299, 334].

Теоретическое и институциональное изучение рассматриваемой темы в контексте исторического развития исследуемого концепта с точки зрения отечественной доктрины возможно и необходимо, по мнению автора, для целей осмысления его сущности и задач.

В-четвертых, осознание сущности исследуемого концепта неразрывно связано с требованиями юридической техники и может быть значимо для развития обычая брифинга актов индивидуального регулирования.

К сожалению, по мнению автора, отечественная правоприменительная практика редко обнаруживает четкое определение установленных фактических обстоятельств. Зачастую, при брифинге фактических обстоятельств дела суды используют исходные тексты позиций сторон, содержащих как информацию о фактах, так и собственные промежуточные правовые выводы. При этом отделить одно от другого может быть затруднительно. Такое изложение правовой позиции как участника правоприменительного процесса, так и его субъекта, при котором фактические обстоятельства, доказательства их подтверждающие, а также вопросы права осознанно и целенаправленно отделены и мотивированы является не только значимым и обязательным правилом юридической техники, но и способом обеспечить наивысший уровень профессиональной культуры.

Таким образом, разграничение вопросов факта и права - непростая задача, особенную значимость приобретающая для правоприме- 
нительного процесса. Это нерушимая структура, обеспечивающая ясность решающего юридическую задачу разума, чистоту и понятность судебного постановления.

Обнаружив в настоящей работе значимость изучаемых явлений для отечественной юри- спруденции в целом и теории права в частности и определив место исследуемого концепта в теории права считаем необходимым дальнейшее изучение и разработку теоретических и практических основ исследуемой темы.

\section{Библиографический список}

1. Алексеев С. С. Общая теория права: курс в двух томах. Т. 1. Москва. 1981. С. 330

2. Андреев Н. Ю. Государственный суверенитет: отделение вопросов права от вопросов факта // История государства и права. Воронеж, 2017. С. 14-19

3. Арбитражный процессуальный кодекс Российской Федерации от 24.07.2002 № 95-Ф3 // Парламентская газета. № 140-141. 27.07.2002.

4. Бабичев Н.Т., Боровский Я. М. Латинско-русский и русско-латинский словарь крылатых слов и выражений. М.: Русский Язык, 1982.

5. Будылин С. В. Вопрос права или вопрос факта? Доказывание и кассация. М.: Закон. 2014.

6. Будылин С.Л. Вопросы права и вопросы факта для математиков // URL: https://zakon.ru/blog/2014/7/11/ voprosy_prava_i_voprosy_fakta_dlya_matematikov (дата обращения: 16.10.2020).

7. рражданский процессуальный кодекс Российской Федерации от 14.11.2002 № 138-Ф3 // Собрание законодательства РФ. 18.11.2002. № 46.

8. Дюрягин И.Я. Применение норм советского права. Свердловск. 1973. С. 49.

9. Ерохова М.А. Научный круглый стол Юридического института «М-Логос» по теме «Проблемы доказывания в гражданском и арбитражном процессе - 3» // URL: http://www.m-logos.ru/img/Tezisy\%20Erokhovoi\%20 M.\%20A._280514.pdf (дата обращения: 16.10.2020).

10. Ершов В.В. Правовое и индивидуальное регулирование общественных отношений. М.: РГУП, 2018. С. 620621.

11. Зеленин Н. Ю. Возникновение и историческое развитие концепта разграничения вопросов факта и права в юриспруденции // Историко-правовые проблемы: Новый ракурс. 2020. № 1. С. 139.

12. Лазарев В. В. Применение советского права. Казань: Изд-во Казан. ун-та, 1972. С. 39-40

13. Марченко М. Н. Теория государства и права. Часть 2. Теория права. М.: Зерцало, 2011. С. 247

14. Матузов Н. И., Малько А. В. Теория государства и права. М.: Юристъ, 2008. С. 273.

15. Мейер Г. (пер.: Таганцев Н. С.). Вопросы факта и права на суде присяжных, в особенности о постановке вопросов присяжным. СПб.: Журн. М-ва юстиции, 1866.

16. Морозова Л.А. Теория государства и права. М.: Юристъ, 2010. С. 244.

17. Определение Верховного Суда Российской Федерации от 29.03.2016 № 305-ЭС15-16362.

18. Постановление Верховного Суда Российской Федерации от 17.11.2014 № 303-АД14-364

19. Постановление Пленума Верховного Суда Российской Федерации от 30 июня 2020 г. № 13 «О применении Арбитражного процессуального кодекса Российской Федерации при рассмотрении дел в арбитражном суде кассационной инстанции» // Российская газета. № 156(8210). 2020.

20. Постановление Президиума Высшего Арбитражного Суда Российской Федерации от 25.07.2011 № 3318/11.

21. Постановления Пленума ВАС РФ от 23.07.2009 г. № 57 «О некоторых процессуальных вопросах практики рассмотрения дел, связанных с неисполнением либо ненадлежащим исполнением договорных обязательств» // Вестник Высшего Арбитражного Суда Российской Федерации. 2009. № 9.

22. Рассказов Л. П. Теория государства и права: углубленный курс: Учебник. М.: РИОР: ИНФРА-М, 2015. С. 400

23. Сардаева О.Г. Установление фактических обстоятельств дела как основа квалификации юридически значимого поведения: дис...канд. юрид. наук. Саратов, 2013.

24. Уголовно-процессуальный кодекс Российской Федерации 18 декабря 2001 г. № 174-ФЗ // Российская газета. 22.12.2001, № 249.

25. Ярцева Л. С. Вопросы права и факта в суде присяжных // Актуальные проблемы борьбы с преступностью в Сибирском регионе. Сборник материалов международной научно-практической конференции. Ч. 2. Красноярск. 2003. С. 175-178.

26. Coke E. The First Part of the Institutes of the Laws of England; or, a Commentary upon Littleton. 19 th ed. Vol. 1. London: 1832. C. [155b] 